\title{
壁面流出入を伴う開水路浸透床上の \\ 乱流構造に関する研究 \\ TURBULENT STRUCTURE IN PERMEABLE OPEN-CHANNEL FLOWS WITH TRANSPIRATION
}

\author{
中 川博 次* - 祢 津 家 久** \\ By Hiroji NAKAGAWA and Iehisa NEZU
}

\section{1. 序論}

壁面を通しての流体の吹出し (injection) や吸込み (suction) によって壁面上の乱流を好ましい姿に制御し ようとする基礎的・応用的研究が境界層流や管路流を対 象として戦後盛んに行われてきた.すなわち, 壁面摩擦 係数 (friction-factor) や熱質量輸送 (heat-mass transfer) に及ぼす壁面流出入 (transpiration といい, injection と suction の総称) の影響を解明する目的で, ま ず 1950 年代には不十分な実験装置ながら実験データの 収集とその予測式の提案が試みられた，例えば，Dorrance ら (1954) ${ }^{1)}$ や Black ら (1958) ${ }^{2)}$ をはじめ多くの 研究者は Prandtl の混合距離モデルを適用し, 壁面流 出入がある場合の壁法則として二乗対数則 (bilog-law) を提案し，実験值とのほぼ良好な一致を得た. 1960 年 代の研究は二乗対数則を踏襲しつつもさらに発展し, Stevenson (1964) は速度欠損則の確立に努め ${ }^{3)}$ Tennekes（1965）は壁法則と速度欠損則との結合を相似則か ら論じようと試みだ). 1960 年代後半からは Stanford 大学の Kays らのグループによる一連の実験が 注目さ れる.すなわち, Simpson ら (1969) ${ }^{5)}$ は壁面流出入率 を流下方向に変化させた境界層流の実験を, Julien ら $(1971)^{6)}$ はさらに圧力勾配も存在する実験をそれぞれ行 い, Kays $(1972)^{7)}$ は以上の平均流特性に及ぼす壁面流 出入の影響に関して総括を行っている. そして, 最近よ うやく流出入を有する境界層流の乱れ計測が Andersen ら (1975) によって行われるに至った ${ }^{8)}$.

以上の実験的研究によって, 吹出しを行えば乱れは活 発化し, 逆に吸込みでは減衰するから, 適当な壁面流出 入を与えることによって乱れの発生を, 広義には流れを

* 正会員 工博 京都大学教授 工学部土木工学教室

** 正会員 工博 京都大学助手 工学部土木工学教室
制御できることが指摘され，事実，乱流剝離防止方法と して吸込み流が，一方高温な流れからの壁面の保護方法 として吹出し流がそれぞれ有効であることが認識され， 航空工学や化学工学等の分野ではすでに一部実用に供さ れている7). このような乱流制御の研究は開水路流を対 象とする水工学の分野でも今後重要な課題と考えられる が，著者らの知る限りこれに関する基礎的研究はほとん どなく ${ }^{9)}$, 著者らはここ数年来多孔質状の水路底から一 様な水流の吹出しや吸込みを与えることによって, 開水 路の乱流構造がいかなる変化を受けるかを系統的に研究 してきた 10) 12),14).

本論文では，これまでに得られた滑面開水路流からの 実験結果を総括する目的で*)，まず流出入を有する壁面 摩擦抵抗則すなわち摩擦速度の合理的な評価方法を確立 し，その平均流速分布則 (壁法則) を統一的に説明する とともに，過大な吸込み率で生じる再層流化現象（relaminarization phenomenon) への遷移挙動に関して検討 する.

次に, 乱れ強度 3 成分, スペクトル分布形, 乱れエネ ルギーの収支等を検討して, 開水路流の乱れ特性に及ぼ す壁面流出入の影響を系統的に考察する.

\section{2. 理論的考察}

\section{（1） 2 次元開水路乱流の基礎方程式}

Fig. 1 に示すように, 主流方向を $x$ 軸, 浸透壁面に 垂直上方を $y$ 軸およびこれに平行な横断方向を $z$ 軸にと り，また対応する流速成分をそれぞれ $U+u, V+v$ お よび $W+w$ とする（以後，大文字は平均流成分を，小 文字は変動成分を表わす). 壁面流出入の影響に関する

*) 本論文は, 文献 10，11）および 14）に一部発表した実験 結果を中心に，さらに検討を加えたものである. 


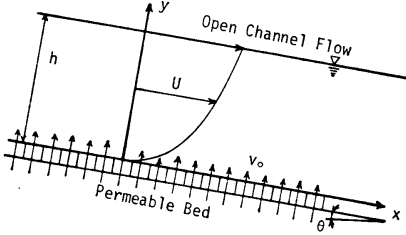

Fig. 1 Open-channel flow over permeable smooth bed
基礎的知見を得る目 的で, (1) 十分に発 達した 2 次元の滑面 乱流である( $W \equiv$ 0), (2) 壁面流出入 速度 $v_{0}$ は浸透面に 垂直で，流下方向に

一様な強度をもち, 主流速に比べて微小である $(U \gg V$ $v_{0}$ ), (3) $v_{0}=0$ では等流であり, $v_{0} \neq 0$ でも擬似等流 であるといら普遍性を失わずにもっとも単純化された流 れを考える.このとき， $y=0 て ゙ ~ V=v_{0}$ といら境界条 件で連続式は次のようになる.

$$
V=v_{0}-\int_{0}^{y}\left(\frac{\partial U}{\partial x}\right) d y
$$

次に, 運動方程式は, (2) から境界層近似を行って次 式で与えられる.

$$
\begin{array}{r}
\frac{\partial\left(U^{2}\right)}{\partial x}+\frac{\partial(U V)}{\partial y}=g \sin \theta-\frac{1}{\rho} \frac{\partial P}{\partial x}+\frac{\partial \tau}{\partial y} \\
\cdots \cdots \cdots \cdots \cdots \cdots \cdots \cdots \cdots \cdots \cdots \cdots \cdots \cdots \cdots \cdots \cdots \cdots \cdots \cdots \cdots \cdots \cdots(3) \\
0=-g \cos \theta-\frac{1}{\rho} \frac{\partial P}{\partial y}+\frac{\partial\left(-\bar{v}^{2}\right)}{\partial y} \cdots \cdots \cdots \cdots \cdots \cdots(3)
\end{array}
$$

ここで, $\theta$ は水路傾斜角, $P$ は圧力, $\tau$ は全せん断応力 である.

水樑を $h$ とすれば, 式 (3) から

$$
P=\rho g(h-y) \cos \theta-\rho\left(\overline{\boldsymbol{v}}^{2}-\overline{\boldsymbol{v}}_{s}^{2}\right)
$$

となり, 圧力はほぼ静水圧分布することがわかる. 式 （1）と式 (4) を式 (2) に代入し， $[0, y]$ 間で積分すれ ば, せん断応力 $\tau$ の分布形が次のように得られる.

$$
\frac{\tau}{\rho}=\frac{\tau_{0}}{\rho}-g I_{e} y+v_{0} U+\Psi(y)
$$

ここで, $\tau_{0} / \rho \equiv U_{*}{ }^{2}$ は壁面せん断応力, $I_{e} \equiv \sin \theta-$ $\cos \theta d h / d x$ はエネルギー勾配であり，

$$
\Psi(y) \equiv \frac{d}{d x} \int_{0}^{y} U^{2} d y-U-\frac{d}{d x} \int_{0}^{y} U d y
$$

は移流項 (advection) を表わす.

自由水面 $y=h$ で $\tau=0$ といら境界条件を使うと,

$$
\begin{aligned}
& \tau / \rho=U_{*}{ }^{2}(1-\xi)+v_{0}\left(U-\xi U_{\max }\right) \\
& +\{\Psi(y)-\xi \Psi(h)\} \\
& U_{*}{ }^{2} \equiv \tau_{0} / \rho=g I_{e} h-\frac{d}{d x} \int_{0}^{h} U^{2} d y
\end{aligned}
$$

となる.ここで, $\xi \equiv y / h$, また $U_{\max }$ は $y=h$ での平 均流速である.

式 (7) の右辺第 2 項 および第 3 項が壁面流出入に伴 う補正項であり， $v_{0}=0$ の不浸透床の等流 $(d / d x=0)$ では零となる. これらの補正項を評価するには平均流速 分布が既知でなければならず，十分に発達した擬似等流 であることから，相似仮定すなわち

$$
U / U_{\max }=\eta(y / h)
$$

が $x$ の位置にはよらないと仮定する. この仮定の妥当 性は, 移流項 $\Psi(y)$ の影響が 開水路流より顕著な境界 層流でさえ一般に認められている $\left(\right.$ 平衡境界層 ${ }^{13}{ }^{13}$.

いま,

$$
\begin{aligned}
& Q_{1} \equiv \frac{1}{U_{\max }} \frac{d}{d x}\left(U_{\max } h\right) \\
& Q_{2} \equiv \frac{1}{U_{\max ^{2}}} \frac{d}{d x}\left(U_{\max ^{2}} h\right) \\
& \Theta_{1}(\xi) \equiv \int_{0}^{\xi} \eta d \xi \\
& \Theta_{2}(\xi) \equiv \int_{0}^{\xi} \eta^{2} d \xi
\end{aligned}
$$

とおけば, 式 (6) は

$$
\Psi(y) \equiv\left\{Q_{2} \Theta_{2}(\xi)-Q_{1} \eta(\xi) \Theta_{1}(\xi)\right\} U_{\max }^{2}
$$

となり, 式 (1) と (10) とから

$$
Q_{1}=\frac{v_{0}}{U_{\max } \theta_{1}(1)}, Q_{2}=2 Q_{1}-\frac{d h}{d x}
$$

が得られ，これらを式 (8) に代入すると，

$$
\frac{d h}{d x}=\frac{\sin \theta-\left(U_{*}{ }^{2} / g h\right)-2 \alpha\left(v_{0} U_{m} / g h\right)}{\cos \theta-\alpha F_{r}{ }^{2}}
$$

となる.ここで, $\alpha \equiv \Theta_{2}(1) /\left(\Theta_{1}(1)\right)^{2}$ は運動量補正係数 であり，例えば $1 / 7$ 乗分布則すなわち $\eta \equiv \xi^{1 / 7}$ を適用 すれば $\alpha=1.016$ となる. また, $U_{m}$ は断面平均流速, $F_{r} \equiv U_{m} / \sqrt{g h}$ はフルード数である.

式（13）は壁面流出入が存在する場合の水面形方程式 である．等流水媣 $h_{0}$ を与える $v_{0}=0$ での摩擦速度を $U_{* 0}$ とおけば, $U_{* 0}{ }^{2}=g h_{0} \sin \theta$ となり, $h \fallingdotseq h_{0}$ と近似 できることから式 (12)，(13）を式（11）に代入すると, 結局式 (7) のせん断応力分布は次のようになる.

$$
\begin{aligned}
& \tau^{+} \equiv \frac{\tau}{\rho U_{*}{ }^{2}}=(1-\xi)+v_{0}{ }^{+}\left(U^{+}-\xi U_{\max ^{+}}\right) \\
& +\Phi(\xi)
\end{aligned}
$$

補正項 $\Phi(\xi) \equiv \Psi^{+}(\xi)-\xi \cdot \Psi^{+}(1)$ は次のように計算され る*).

$$
\begin{aligned}
\Psi^{+}(\xi)= & \frac{1}{\left(\cos \theta-\alpha F_{r}^{2}\right)}\left\{\left(\frac{F_{r}}{\Theta_{1}(1)}\right)^{2}\left(1-\frac{1}{\Omega}\right)\right. \\
& \left.+\frac{2 v_{0}^{+} U_{\text {max }^{+}}}{\Theta_{1}(1)}\right\} \Theta_{2}(\xi)
\end{aligned}
$$

*）文献 14）では, 自由水面でのせん断応力勾配は適度の流 出入率が存在しても不変である, すなわち

$$
\left.\frac{d \tau}{d \xi}\right|_{\xi=1}=\left.\frac{d \tau\left(v_{0}=0\right)}{d^{\xi}}\right|_{\xi=1}=-\rho U_{* 0}^{2}
$$

という実験結果に注目して,

$$
\begin{aligned}
\Psi^{+}(\xi)= & \frac{1}{\left\{1-\Theta_{2}(1)\right\}}\left\{\left(1-\frac{1}{\Omega}\right)+\frac{v_{0}{ }^{+} U_{\max }{ }^{+}}{\Theta_{1}(1)}\right\} \Theta_{2}(\xi) \\
& -\frac{v_{0}{ }^{+} U_{\max }{ }^{+}}{\Theta_{1}(1)} \eta \cdot \Theta_{1}(\xi)
\end{aligned}
$$

を導いたが，式 (15) との差異は常流であれば無視されうる。 


$$
-\frac{v_{0}^{+} U_{\max ^{+}}}{\Theta_{1}(1)} \cdot \eta \cdot \Theta_{1}(\xi)
$$

ここで, $\Omega \equiv\left(U_{*} / U_{*_{0}}\right)^{2}=\tau /\left.\tau\left(v_{0}=0\right)\right|_{\xi=0}$ であり, +添 字は $U_{*}$ と (内部パラメーター) に上る無次元化を 表わす（例えば， $v_{0}{ }^{+} \equiv v_{0} / U_{*}, y^{+} \equiv U_{*} y / \nu$ など).

したがって, 平均流速分布形 $\eta(\xi)$ が既知であれば補 正項 $\Phi(\xi)$ は式 (15) で評価され，例えば $1 / 7$ 乗分布 則を適用し,フルード数が十分小さい常流では $|\Phi(\xi)|=$ $(7 / 9)\left|v_{0}{ }^{+} U_{\max }{ }^{+} \xi\left(\xi^{2 / 9}-1\right)\right| \leqq 0.072 v_{0}{ }^{+} U_{\text {max }^{+}}$となって, 無視されらる值となる*).

\section{（2）壁面流出入を伴う平均流速分布則（壁法則）}

レイノルズ応力分布 $-\overline{u v}$ は

$$
\frac{-\overline{u v}}{U_{*}^{2}}=\tau^{+}-\frac{d U^{+}}{d y^{+}}
$$

で与えられ， $\xi \ll 1$ なる壁面近傍では式 (14) から次の ように近似される。

$$
\frac{-\overline{u v}}{U_{*}{ }^{2}}=1+v_{0}{ }^{+} U^{+}-\frac{d U^{+}}{d y^{+}}
$$

さて，十分に発達した壁面乱流では混合距離モデルが適 用できるから ${ }^{7), 15) ，}$

$$
\frac{d U^{+}}{d y^{+}}=\frac{2\left(v_{0}^{+} U^{+}+1\right)}{1+\sqrt{1+4 l^{+2}\left(v_{0}^{+} U^{+}+1\right)}}
$$

となる. 壁面流出入を伴う境界層流に関する Kays らの グループの実験結果によれば5) 8), 混合距離（特性長さ スケール） $l^{+}$として次の van Driest 型のものが妥当で ある.すなわち，

$$
l^{+}=\kappa_{0} y^{+}\left\{1-\exp \left(-y^{+} / A^{+}\right)\right\}
$$

ここで, $\kappa_{0}$ はカルマン定数, $A^{+}$は粘性効果を示す減衰 倸数 (damping factor) である.

例えば，粘性底層では $l^{+} \ll 1$ であるから，式 (18) よ り

$$
U^{+}=\frac{1}{v_{0}^{+}}\left\{\exp \left(v_{0}^{+} y^{+}\right)-1\right\}
$$

となり, $l^{+} \gg 1$ すなわち $y^{+} \gg A^{+}$では式 (18) と式 (19) とから次式が得られる。

$$
\begin{aligned}
& \phi \equiv \frac{2}{v_{0}^{+}}\left(\sqrt{v_{0}^{+} U^{+}+1}-1\right)=\frac{1}{\kappa_{0}} \ln y^{+} \\
& +D\left(v_{0}^{+}\right)
\end{aligned}
$$

式 (21) は, Dorrance らが最初に導いた二乗対数則で あり ${ }^{1)}$, その後多くの研究者がこの式の妥当性を境界層 流で実験的に検討し, その結果, カルマン定数 $\kappa_{0}$ は $v_{0}{ }^{+}$ に無関係な普遍定数であるが, 積分定数 $D$ は一般に浸 透面性状や $v_{0}^{+}$によって影響を受けることが報告され $た^{2) \sim 8)}$. しかし, 浸透面が水理学的滑面であり, 適度の 流出入率であれば $D$ はほぼ定数とみなされらるから (吹出し流の方が適用度がよい) ${ }^{15)}, 16$, 以下では $v_{0}{ }^{+} \rightarrow$ 0 のとき式 (21) が開水路不浸透床上の対数則に一致す
るといら条件から $\kappa_{0}=0.4$ および $D=5.5$ をとるもの と仮定し, この妥当性法後で実験的倹証される.

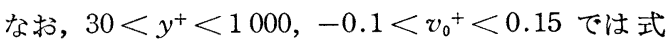
(21) の二乗対数則は, 次の対数則で近似される ${ }^{17)}$. す なわち,

$$
U^{+}=\frac{1}{\kappa} \ln y^{+}+B
$$

ここで, $\kappa \equiv \kappa_{0}\left(1+9.2 v_{0}^{+}\right)^{-1}, B \equiv D\left(1-D v_{0}^{+}\right)$

式 (22) は相似則から 経験的に求めた Tennekes の表 示式とほぼ一致し ${ }^{4), 15)}$, この場合カルマン定数 $\kappa$ は見 かけ上 $v_{0}{ }^{+}$の関数となるが, $v_{0}{ }^{+}=0$ での汎用の対数則 分布をそのまま $v_{0}^{+} \neq 0$ の場合に拡張したものであるか ら，実用価值は大きいと考えられる.

さて, 式 (20) と式 (21) とを滑らかに接続する普遍 的な壁法則は式 (19) を使って式 (18) を数值積分すれ ば得られる。

後で示すように,過大な吸込みで再層流化現象に,吹出 しで剝離現象にそれぞれ遷移することから，粘性の効き 具合を表わ寸係数 $A^{+}$は $v_{0}^{+}$の関数と考えられ(6) 8),18), 本研究では式 (18) の数值解が壁面領域端 $\delta^{+}=100$ で 式 (21) に接続するように係数 $A^{+}$を決定し, 流速分 布則（壁法則）を得ることにした.

\section{（3）摩擦速度の評価方法(流出入を伴う壁面抵抗則)}

壁面乱流の構造を明らかにするには, まず摩擦 速 度

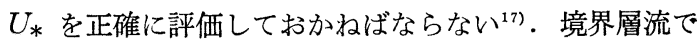
の Kinney の解析と同様にして ${ }^{16)}$, 式 (21) を全水深で 積分し, $v_{0}=0$ で成立する Prandtl-Karman の抵抗則, すなわち

$$
\sqrt{2 / f_{0}}=2.5 \ln \operatorname{Re} \sqrt{f_{0} / 2}+3.0
$$

との比をとれば次の壁面抵抗則が得られる.

$$
\begin{gathered}
\left(\frac{1-\sqrt{\Omega}-1.25 \beta \ln \sqrt{\Omega}}{\sqrt{\Omega}}\right)\left(\frac{f_{0}}{2}\right)^{-1 / 2} \\
-\frac{\beta}{4 \sqrt{\Omega}}\left(\frac{f_{0}}{2}\right)^{-1}=2.5 \ln \sqrt{\Omega} \\
+\frac{\beta}{4 \sqrt{\Omega}}\left\{(2.5 \ln \sqrt{\Omega})^{2}+6.25\right\}
\end{gathered}
$$

(二乗対数則から)

同様に, 式 (22) の対数則を用いれば次のようになる.

$$
\begin{aligned}
& \left(\frac{1-\sqrt{\bar{\Omega}}-9.2 \beta}{\sqrt{\Omega}}\right)\left(\frac{f_{0}}{2}\right)^{-1 / 2} \\
& =2.5\left(1+9.2 \frac{\beta}{\sqrt{\Omega}}\right) \ln \sqrt{\Omega}-80.9-\frac{\beta}{\sqrt{\Omega}}
\end{aligned}
$$$$
\text { (対数則から) }
$$

ここで, $\beta \equiv v_{0} / U_{* 0}, \quad f_{0} \equiv 2\left(U_{*_{0}} / U_{m}\right)^{2}, R e \equiv h U_{m} / \nu$ である. Fig. 2 は， 5 通りのレイノルズ数 $R e$ に関し て式 (23) を使って式 (24) および（25）から計算され た $\beta-\Omega$ 曲線である。 


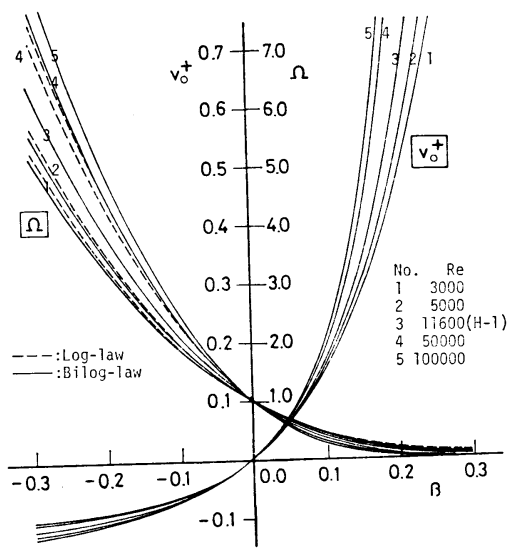

Fig. $2 \beta-\Omega$ and $\beta-v_{0}{ }^{+}$relations

$|\beta| \leqq 0.2$ では式 (24) と式 (25) との差異は小さく ( $R e \simeq 10^{4}$ で両者はほぼ一致する), 式 (21) の二乗対数 則は式 (22) の対数則で良好に近似されることがわか る. 吹出し $(\beta>0)$ では $\Omega \equiv\left(U_{*} / U_{*_{0}}\right)^{2}$ は減少し, $\beta$ $\simeq 0.3$ 程度で $\Omega \simeq 0$ すなわち剝離現象を示すのに対し て, 吸込み $(\beta<0)$ では $\Omega$ 㴔増し, 流速勾配 $d U /$ $\left.d y\right|_{y=0}=U_{*}{ }^{2} / \nu$ も増大して, 後述するように再層流化一 と遷移する．また，図には $v_{0}{ }^{+}=\beta / \sqrt{\Omega}$ を併示したが， 流出入速度 $\left|v_{0}\right|$ の増加に対して $v_{0}{ }^{+}$は吹出しで急増し, 吸込みでは - 0.1 程度に収束することが注目される。

壁面抵抗すなわち摩擦速度に及ぼすこれらの流出入によ る効果は圧力勾配 $d P / d x$ が存在する境界層や管路流の 挙動と酷似し, すなわち吹出しが減速流 $(d P / d x>0$ の急拡部) に, 吸込みが加速流 $(d P / d x<0$ の急縮部 $)$ にそれぞれ対応し，両極端で剝離現象と再層流化現象が それぞれ観察される ${ }^{19}$.

さて著者らは, $\beta=0$ の不浸透 床での $U_{* 0}$ を乱れの self-consistency に従って実測のレイノルズ 応力分布, 寸なわち $\tau\left(v_{0}=0\right) / \rho=$ $U_{* 0}{ }^{2}(1-\xi)$ から評価するのがも っとも合理的であることを指摘し た ${ }^{20)}$. したがって， $U_{* 0}$ が既知と なれば，任意の $\beta$ に対して $U_{*}=$ $\sqrt{\Omega} U_{* 0}$ は式 (24) から容易に評 価される (以下では, この評価方 法を $\beta-\Omega$ 法という).

\section{3. 実験装置および計測方法}

Fig. 3 に示すよらに, 実験水 路は長さ $15 \mathrm{~m}$, 幅 $50 \mathrm{~cm}$, 深さ 30 $\mathrm{cm}$ の勾配可変型の循環式滑面開

Case $\mathrm{H}-\mathrm{I}$

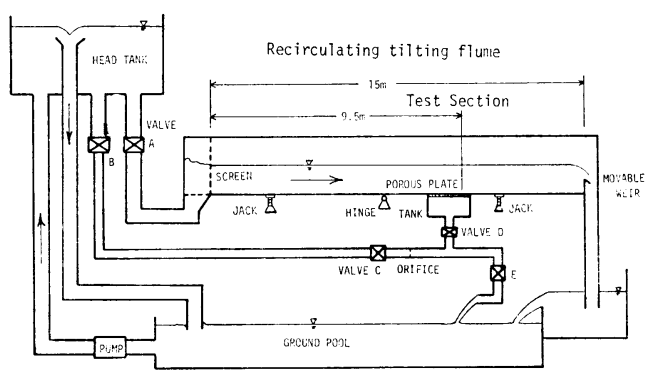

Fig. 3 Experimental set-up

水路で, 水路上流端から約 $9 \mathrm{~m}$ 下流に小型水槽（長さ 96 $\mathrm{cm}$, 幅 $41 \mathrm{~cm}$, 深さ $30 \mathrm{~cm}$ ) を設け,この直上に長さ 104 $\mathrm{cm}$, 幅 $49 \mathrm{~cm}$, 厚さ $1.5 \mathrm{~cm}$ のポーラス板(粒径 $0.65 \mathrm{~mm}$ のポリスチレン樹脂の熱焼結滑面板) を取付け, 計測区 間とした.この水槽底面には直径 $2.5 \mathrm{~cm}$ の給排水口が 8 個拉よび水槽中央部には制流装置がそれぞれ設けられ， 一様な流出入速度 $v_{0}$ が得られるように工夫された. 水 槽内の圧力分布の計測から一様な $v_{0}$ が生じていること を確認後, 流出入流量 $Q_{t}$ が吹出しでオリフィス計, 吸 込みで計量マスをそれぞれ用いて計測され，vが゙決定 された。もちろん，ポーラス区間は長いほど実験的研究 に理想的であるが, 透水・不透水両壁面ともに水理学的 滑面であり，正確に同一面上に接続されたから壁面の相 違による内部境界層の発達はほぼ無視できるものと考え られ，また v。 を急変させた境界層流の実験によれば少 なくとも平均流特性 はほとんど遷移区間なしに新たな $v_{0}$ に応答することが報告され の実験的検証が十分可能である. 計測断面はポーラス板 の上流端から $x=84 \mathrm{~cm}$ 下流に設けられたが, $x=50 \mathrm{~cm}$ での平均流速分布と比較検討された結果, 両者は実験誤

Table 1 Hydraulic data for experiments with suction or injection

\begin{tabular}{|c|c|c|c|c|c|c|c|c|}
\hline Case & $\begin{array}{c}\mathrm{h} \\
(\mathrm{cm})\end{array}$ & $\begin{array}{c}U \mathrm{~m} \\
(\mathrm{~cm} / \mathrm{sec})\end{array}$ & $\begin{array}{c}U_{\star \circ} \\
(\mathrm{cm} / \mathrm{sec})\end{array}$ & $\begin{array}{l}R_{\star} \circ \\
=U_{\star} \circ h / v\end{array}$ & $\begin{array}{l}\mathrm{Re} \\
=U_{m} \mathrm{~h} / \mathrm{V}\end{array}$ & $\begin{array}{l}F r \\
=U_{m} / \sqrt{g h}\end{array}$ & $\begin{array}{c}\text { S } \\
\text { slope }\end{array}$ & $\begin{array}{c}Q \\
(1 / \mathrm{sec})\end{array}$ \\
\hline $\mathrm{H}-1$ & 8.02 & 15.1 & 0.804 & 609 & $1.15 \times 10^{4}$ & 0.17 & $0.08 \times 10^{-4}$ & 6.05 \\
\hline $\mathrm{H}-2$ & 4.25 & 28.3 & 1.369 & 564 & 1.16 & 0.44 & 5.71 & 6.00 \\
\hline $\mathrm{H}-3$ & 3.40 & 35.4 & 1.907 & 614 & 1.14 & 0.61 & 12.84 & 6.02 \\
\hline
\end{tabular}

Vo $\neq 0$ (With transpiration flow)

\begin{tabular}{l|ccccccccccc} 
Run & 15 & 14 & 13 & 9 & 8 & 1 & 4 & 5 & 10 & 11 & 12 \\
\hline$U_{*}$ & 1.760 & 1.585 & 1.316 & 1.146 & 0.980 & 0.804 & 0.641 & 0.523 & 0.373 & 0.271 & 0.193 \\
$\beta$ & -0.243 & -0.202 & -0.137 & -0.094 & -0.050 & 0.0 & 0.049 & 0.089 & 0.148 & 0.198 & 0.249 \\
$\mathrm{~V}_{0}^{+}$ & -0.111 & -0.102 & -0.084 & -0.066 & -0.041 & 0.0 & 0.062 & 0.136 & 0.319 & 0.539 & 1.036 \\
$Q_{t} / Q$ & $-12.6 \%$ & -10.5 & -7.1 & -4.9 & -2.6 & 0.0 & 2.5 & 4.6 & 7.7 & 10.2 & 12.9
\end{tabular}

\begin{tabular}{|c|c|c|c|c|c|}
\hline \multirow[b]{2}{*}{ Run } & \multicolumn{2}{|c|}{ Case $\mathrm{H}-2$} & \multirow[b]{2}{*}{1} & \multirow[b]{2}{*}{4} & \multirow[b]{2}{*}{5} \\
\hline & 9 & 8 & & & \\
\hline$U_{*}$ & 2.066 & 1.684 & 1.369 & 1.062 & 0.799 \\
\hline$\beta$ & -0.111 & -0.052 & 0.0 & 0.056 & 0.111 \\
\hline$v_{0}^{+}$ & -0.074 & -0.042 & 0.0 & 0.072 & 0.189 \\
\hline$Q_{t} / Q$ & -9.9 & -4.6 & 0.0 & 5.0 & 9.9 \\
\hline
\end{tabular}

Case $\mathrm{H}-3$

\begin{tabular}{ccccc}
\hline 8 & 7 & 1 & \multicolumn{1}{c}{4} & \multicolumn{1}{c}{5} \\
\hline 2.307 & 2.166 & 1.907 & 1.509 & 1.147 \\
-0.047 & -0.031 & 0.0 & 0.051 & 0.104 \\
-0.039 & -0.027 & 0.0 & 0.065 & 0.172 \\
-5.8 & -3.8 & 0.0 & 6.3 & 12.8
\end{tabular}


差内で一致し，ほぼ十分に発達した流出入を伴う流れが 形成されたものと考えられる ${ }^{17)}$.

平均流速 $U$ の計測には 1 成分熱膜流速計 (DISA 社 製）が使われ，最低 $y=0.7 \mathrm{~mm}$ まで計測された. また， $u$ と $v$ および $u$ と $w$ の計測には 2 成分 $V$ 型プロー ブが使われ, これらの出力電圧は $\mathrm{A} \cdot \mathrm{D}$ 変換後, 電算処 理された. なお, 詳しい計測方法に関しては文献 17) を 参照されたい.

次に, 水理条件は, $R e \fallingdotseq 10^{4}$ で水深 $h$ を $8 \mathrm{~cm}$ （ケー ス $\mathrm{H}-1$ ), $4.3 \mathrm{~cm}$ (ケース $\mathrm{H}-2$ ) および $3.4 \mathrm{~cm}$ (ケース $\mathrm{H}-3)$ の 3 通り設定した (Table 1 を参照). ケース $\mathrm{H}$ -1 が中心的な実験であり， $\beta$ を約 $\pm 5 \%$ 増分させて計 11 通りの流出入率を系統的に与え, ケース $\mathrm{H}-2$ および H-3 では $\beta$ をそれぞれ 5 通り変化させた. なお, 主流 量 $Q$ に対するこれらの流出入流量 $Q_{t}$ の比はたかだか 13\% 以内であり, 2.(1) の擬似等流の条件がほぼ満足 されている.

\section{4. 実験結果およびその考察}

\section{（1）平均流速分布特性}

Fig. 4 は, 実測された平均流速分布の一例である. 吹出しで低流速域が壁面から押し上げられ, 一方吸込 みでは高流速域が壁面へ吸い寄せられた形となってお り, $\beta$ が \pm 0.1 以内でも流出入の影響は顕著であって, 壁面せん断応力 $\tau_{0} \equiv \mu d U /\left.d y\right|_{y=0}$ は吹出しで減少し, 吸込みで増加することがわかる.これらの平均流速分布 特性を詳細に検討するには，2.(2) で明らかにしたよう に, $U^{+} \equiv U / U_{*}$ および $y^{+} \equiv y U_{*} / \nu$ による無次元表示 が必要である.

まず, Fig. 5 は, ケース H-1 の吹出し条件で得ら れた流速分布の実測值であり, 実線は式 (18) の数值解 である．壁面領域はもちろんのこと，自由水面にまで至

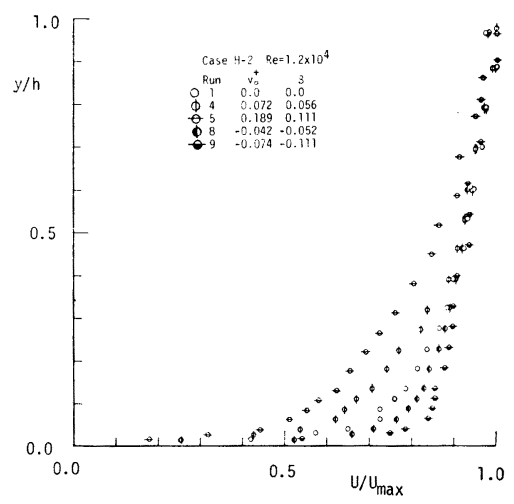

Fig. 4 Mean velocity distribution with suction or injection

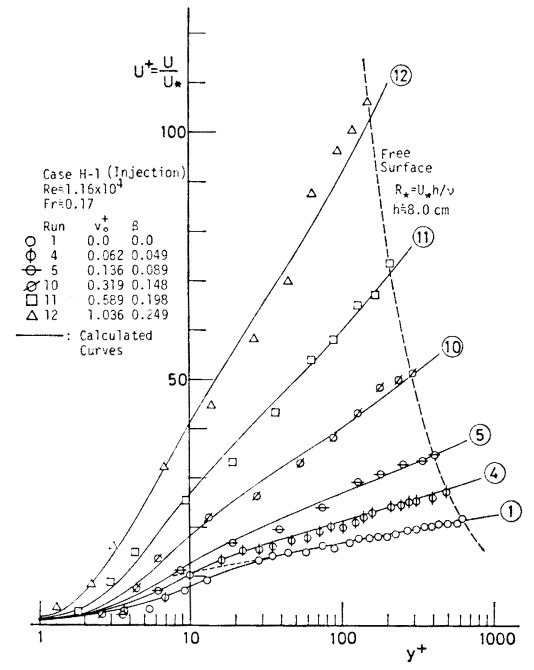

Fig. 5 Dimensionless mean velocity distribution $U^{+}$with injection (Case $\mathrm{H}-1$ ) (the law of the wall)

る全領域で両者の一致は非常によい. すなわち, 開水路 流には境界層流で見られる乱流・非乱流運動 (intermittent な bulges 運動) は存在せず, 式 (18) の混合距 離モデルの有効性がほぼ全領域で認められるが*), 特に 剝離現象へ遷移する $v_{0}^{+} \simeq 1$ という過大な吹出し率でも このモデルは有効であって, 十分に発達した乱流が形成 されていることがわかる。

Fig. 6 は, 吸込み条件での平均流速分布である. $v_{0}^{+}$ 〜ー0.085 程度までの適度の吸込み率では式 (18) はな お有効であるが, これ以上の吸込み率では実験值との一 致は悪く，もはや乱流状態を維持できず，後述するよう に再層流化したものと考えられる.

Fig. 7 は,Fig. 4 で示されたケース H-2 の平均流

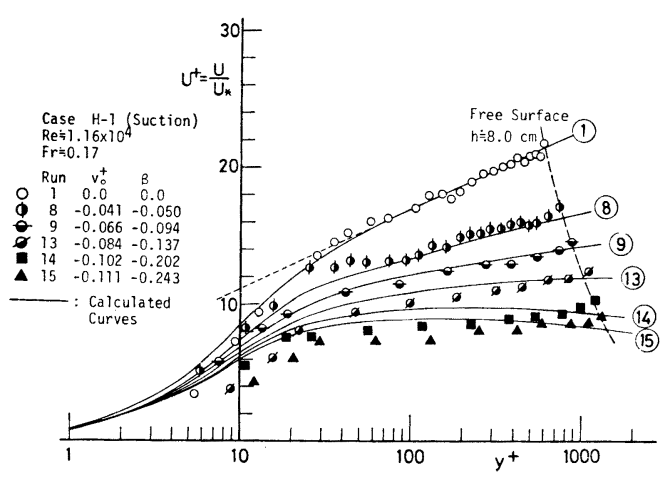

Fig. 6 Dimensionless mean velocity distribution $U^{+}$with suction (Case $\mathrm{H}-1$ ) (the law of the wall)

*) 式 (18),(19) はもともと $\xi \equiv y^{+} / R_{*} \ll 1$ の壁面近傍で成 立する関係式であるが, これらの積分形で表示される平均流速 分布式は自由水面までほぼ有効であることが理論的に示される. 詳細は文献 17）を参照されたい. 


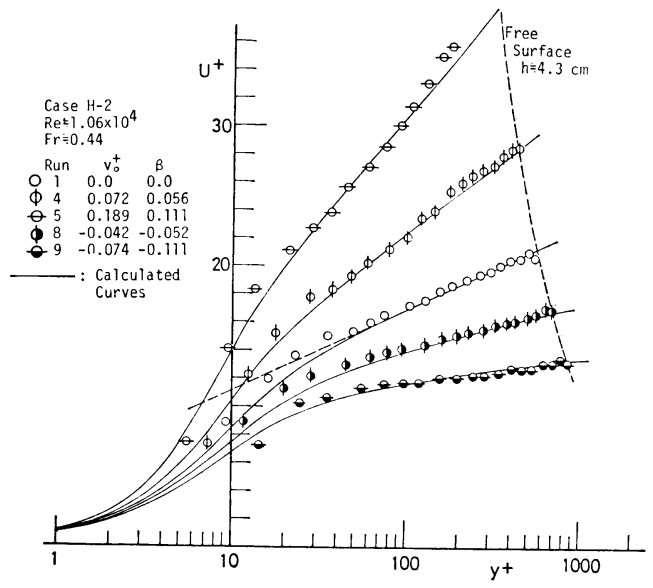

Fig. 7 Dimensionless mean velocity distribution with suction or injection (Case $\mathrm{H}-2$ )

速を壁法則に従って $U^{+}-y^{+}$で表示したものであり， ケース H-1 と同様に普遍的な特性が把握される. すな わち, $v_{0}=0$ での曲線 $\left(y^{+}>30\right.$ で 対数則に従い, $y^{+}$ $<30$ では $A^{+}=27$ とおいた式 (18)，(19)の van Driest 曲線）を基準として吹出しで増大傾向，吸込みで減少傾 向を示す扇状の分布形を示す点が特徴的である.この実 測值と式（18）の理論曲線との一致は粘性底層を含めた 全領域で非常に良好であり，同様な結果がケース $\mathrm{H}-3$ でも得られた。

Fig. 8 は, 二乗対数則 $\phi-y^{+}$の関係を検討したも のである. Run $14\left(v_{0}{ }^{+}=-0.102\right)$ や Run $15\left(v_{0}{ }^{+}=-\right.$ $0.111)$ では $\left(v_{0}^{+} U^{+}+1\right)<0$ となるため $\phi$ 実験值は 得られず, $v_{0}^{+}=-0.084$ の Run 13 でも実験值は式 (18) の理論曲線から明らかにずれ，二乗対数則は成立 していない. 一方, $v_{0}{ }^{+} z-0.08$ となる他の Run の流 出入率では理論曲線との一致は非常によく,特に $y^{+} z 30$ の主流域では吹出し・吸込み率によらずに $\phi$ は式 (21) に良好に従っている.すなわち，後述する再層流化に至 らない適度の吸込みおよび吹出し条件でも，粘性効果が 無視できる $y^{+} \geq 30$ の主流域 (吹出し条件ほど粘性底層

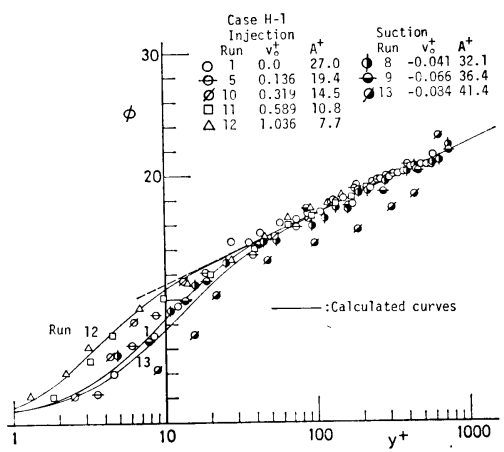

Fig. 8 Bilog-law of mean velocity

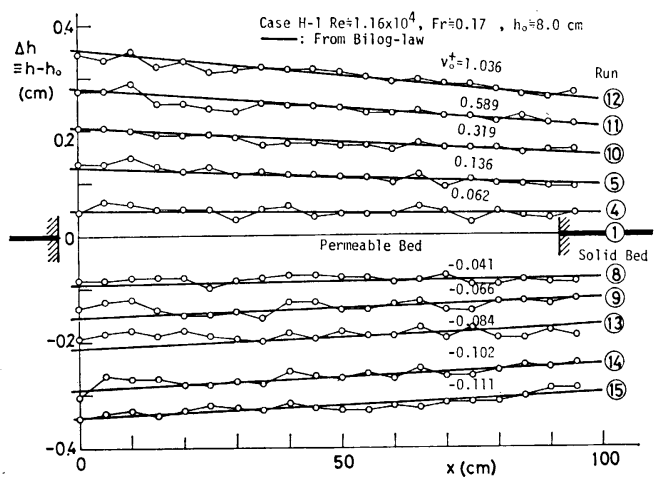

Fig. 9 Variation of flow depth with suction or injection

は薄くなり，Fig. 8 に示すように式 (21) の適用領域 は若干広くなる）の流速分布は， $U^{+}$の代りに れば式 (21) の従来の対数則 $\left(\kappa_{0}=0.4, D=5.5\right)$ で表 示され，普遍的な壁法則を示すことがわかる.

\section{（2）水面勾配 $d \boldsymbol{h} / \boldsymbol{d} \boldsymbol{x}$ の検討}

前節で示されたように，十分に発達した乱流状態では 混合距離モデルが有効となるが, 摩擦速度 $U_{*}$ の評価 に式 (21) が使われたため,この明白な結論付けには $U_{*}$ を $\beta-\Omega$ 法とは独立に評価すべきである.この検討には， (1) 水面勾配, (2) 実測のレイノルズ応力分布, 等からな されらるが20)，ここではまず (1) を検討する.

さて, 水面勾配 $d h / d x$ の実測值が得られれば, 式 （13）を使って $U_{*}$ が評価される．この方法は，境界層 流で式 (8) と同等な 関係式を使い，すなわち運動量厚 の変化から評価するものに相当するが, 両法ともに誤差 を伴いやすい( ${ }^{8,20)}$. Fig. 9 は, ケース $\mathrm{H}-1$ の各実験 で得られた $\Delta h \equiv\left(h-h_{0}\right)$ の実測值と $\beta-\Omega$ 法で評価し た $U_{*}$ を式 (13) に代入して求められた $d h / d x$ とを比 較したものである. $x$ が約 $50 \mathrm{~cm}$ までは不浸透-浸透床 の接続部での流出入の急変に伴ら影響を受けて(この影 響は比較的短区間で消滅するが5) , 実測值は式 (13) か ら若干ずれるが， $x$ が $50 \mathrm{~cm}$ 以上の計測区間では両者 の一致は吹出し・吸込み条件ともにかなり良好であり， 本研究で提案された $\beta-\Omega$ 法による $U_{*}$ の評価がほぼ妥 当であることが確認された。

なお, 式 (24) を $\Omega \fallingdotseq(1-5 \beta)^{2}$ で近似し, $\cos \theta \fallingdotseq 1$, $\alpha \fallingdotseq 1, U_{m} / U_{* 0} \fallingdotseq 20$ とおけば，式（13）の近似式として 次式が得られる.

$$
\frac{d h}{d x} \fallingdotseq \frac{-5 \beta(6+5 \beta) \sin \theta}{1-F_{r}{ }^{2}}
$$

すなわち，常流 $\left(F_{r}<1\right)$ では吹出し $(\beta>0)$ で低下 背水, 吸込み $(\beta<0)$ でせき上げ背水となることがわ かり，Fig.9 と一致した水面形を与える. 


\section{（3）強い吸込み率による不完全乱流遷移（再層流化 現象)}

先述したように，強い吸込み率では乱流状態がもはや 維持されず，その結果混合距離モデルが適用できなくな る. 境界層流では，これを再層流化現象と呼んでいるが （境界層の発達が抑えられ，過大な吸込み率では境界層 厚自体が流下方向に減少し, 再層流化する) ${ }^{2), 4)}$, 開水路 流では一般に流出入流量 $Q_{t}$ が主流量 $Q$ のたかだか 1 割程度を対象とするから，レイノルズ数は依然十分大き く，定義通り流れが層流に逆遷移するとみなすべきでは なく, 十分に発達した乱流から強制的に不完全な乱流状 態に遷移される現象とみるべきである.このような現象 は, 加速流 $(d P / d x<0)$ を伴う境界層や管路流でも観 測され ${ }^{19)}$, 各種の流れに関して統一的な説明や遷移基準 の設定が望まれる.

ところで, Huffman らは，壁面流出入や圧力勾配な どの外部因子は流れが乱流である限り，せん断応力勾配 $\partial \tau / \partial y$ を介して内部層（壁面領域）に影響を及ぼすこと を指摘した ${ }^{21)}$. いま, 彼らと同様にして, 壁面領域端 $\delta^{+}=100$ までのせん断応力の平均勾配を $<\partial \tau / \partial y>$ と すれば, 式 (14) から次式が得られる.

$$
\begin{aligned}
-\left\langle\frac{\partial \tau^{+}}{\partial y^{+}}\right\rangle= & -\frac{v_{0}^{+} U^{+}\left(\delta^{+}\right)}{\delta^{+}}+\frac{1+v_{0}^{+} U_{\text {max }}{ }^{+}}{R_{*}} \\
& -\frac{\Phi\left(\delta^{+}\right)}{\delta^{+}} \cdots \cdots \cdots \cdots \cdots \cdots \cdots \cdots \cdots \cdots \cdots \cdots \cdots \cdots \cdots \cdots
\end{aligned}
$$

Fig. 10 は $R e=1.16 \times 10^{4}$ での $-<\partial \tau^{+} / \partial y^{+}>$を $\left(-v_{0}^{+}\right)$に対して図示したものであり, 式 (27) の右辺 第 3 項の補正項は式 (15) で示すようにフルード数 $F_{r}$ の関数であるから， $F_{r}=0.17,0.6,0.8,1.2$ および 1.5 の 5 通りに関して計算されている. 吸込み率 $\left|-v_{0}^{+}\right|$が 増加すると, 第 1 項は単調に増加し, 第 2 項は単調に減 少して, $F_{r}$ が小さいとき第 3 項の寄与は小さいから, 結 局第 1 項が主要項となって $-<\partial \tau^{+} / \partial y^{+}>$は $\left(-v_{0}{ }^{+}\right)$ ح0.1 程度まで単調に増加する.ところで, 式 (21) は $y_{M^{+}}=\exp \left\{-\kappa_{0}\left(D+2 / v_{0}{ }^{+}\right)\right\}$で最大值 $U_{M^{+}}=-1 / r^{\prime}{ }^{+}$を 計算上はもち, 式 (18) \& $y^{+}=y_{M^{+}}$で $d U^{+} / d y^{+} \equiv 0$ となるから， $y_{M^{+}}<R_{*} \equiv h U_{*} / \nu$ なる 水理条件では混

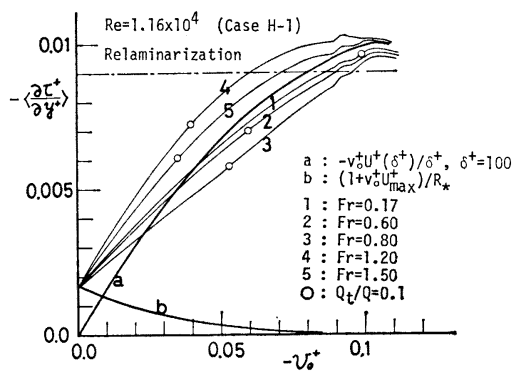

Fig. 10 Average gradient of the shear stress
合距離モデル 自体の適用が不可となる. 物理的にいら と, $y_{M^{+}} \leq y^{+} \leq R_{*}$ では式 (17) から $-\overline{u v} \equiv 0$ とな り，レイノルズ応力すなわち乱れはほとんど発生せず, もはや完全な乱流とは考えられない. 4.(1) で指摘した ように, $F_{r}=0.17$ のケース $\mathrm{H}-1$ では $\left(-v_{0}{ }^{+}\right) \geq 0.085$ で二乗対数則は適用されず，不完全乱流（再層流化）に 遷移したものと考えられた. 実際, Run 13 では $R_{*}=$ 997, $v_{0}^{+}=-0.084, y_{M^{+}}=1516$ ，また Run 14 では $R_{*}$ $=1200, v_{0}{ }^{+}=-0.102, y_{M^{+}}=282$ となるから, $\left(-v_{0}{ }^{+}\right)$ が 0.085 程度以上になれば再層流化するであろう.ま た， $F_{r} \rightarrow 0$ に相当する境界層流でも $\left(-v_{0}^{+}\right)$がほぼ 0.1 に達したとき再層流化現象が起きると報告されてい る $^{2), 4)}$.

以上から,フルード数が 0.2 程度以下の開水路流 で も $\left(-v_{0}{ }^{+}\right)$がほぼ 0.085 に達したとき再層流化が起こ るものと考えられ，これに対応寸る $-<\partial \tau^{+} / \partial y^{+}>$の 限界值は約 0.009 となる.

一方, Patel らは, 境界層や管路流での 加速流 (dP) $d x<0)$ による再層流化現象 に関する詳細な 実験的研 究を行い, これらの遷移限界は壁面領域でのせん断応力 分布に原因があって, overall なレイノズル数 Re の減 少によるものではないことを指摘した ${ }^{19)}$. すなわち, Townsend 流の混合距離モデルを適用して, せん断応力 分布が

$$
\tau=\tau_{0}+\alpha y
$$

と表わされるとき, $\Delta_{\tau} \equiv \nu \alpha / \rho U_{*}^{3}$ なるパラメーターが約 一0.009 に達すれば再層流化が起こることを明らかにし た. 式 (28) は式 (7) の一般形とみなしうるから, パ ラメーター $\Delta_{\tau}$ が $<\partial \tau^{+} / \partial y^{+}>$と同等となる. 以上の結 果から吸込み流や加速流による再層流化の遷移限界值は ほぼ一致し, 両者の内部機構は類似したものであると考 えられる.さらに, $v_{0}=0$ での不浸透床では式 (27) か ら $-<\partial \tau^{+} / \partial y^{+}>=1 / R_{*}$ となり, $<\partial \tau^{+} / \partial y^{+}>_{c}=-$ 0.009 で $R_{e, c}=\left(U_{m} / U_{* 0}\right) R_{*} \simeq 20 / 0.009=2222$ となっ て, 通常の限界レイノルズ数にほぼ一致し, 上述の遷移 限界値はこの場合にも適用できる.

このように, $<\partial \tau^{+} / \partial y^{+}>_{c} \simeq-0.009$ を遷移限界值 とすると, Fig. 10 から同一の吸込み率でも $F_{r}$ が増加 するに従って常流では再層流化が若干抑制され, 射流に 移行して急速に促進されるが， $F_{r}$ の増加とともに再び 抑制されることがわかる.これは, 式 (14) の補正項 $\Phi(\xi)$ が常流では正となり， $F_{r}$ が大きいほどレイノル ズ応力の発生が促進され，再層流化が逆に抑制されるた めである. しかし， $R_{e}$ が一定で, $F_{r}$ を増加させて行 くと $U_{* 0}$ が増加し, $h$ は減少するから同一の吸込み率 を与えるには吸込み流量 $Q_{t}$ を増加させねばならず, 本 研究の前提である 擬似等流状態が 崩れてしまう． Fig. 


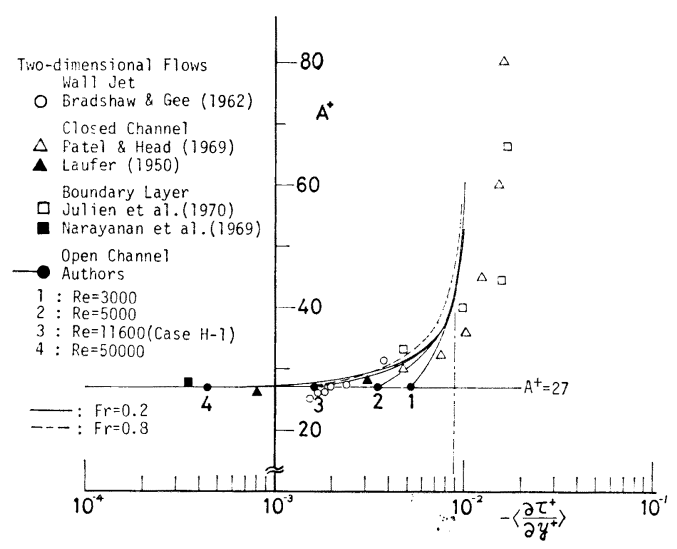

Fig. 11 Relation of $A^{+}$vs. $-\left\langle\partial \tau^{+} / \partial y^{+}\right\rangle$

10 には, $Q_{t} / Q=0.1$ となる $v_{0}^{+}$の值を各 $F_{r}$ に対し て丸印で示している.

以上を総括すると， $\left|Q_{t} / Q\right| \leq 0.1$ なる擬似等流の再層 流化が起こる遷移限界は上述の $<\partial \tau^{+} / \partial y^{+}>\simeq-0.009$ または $v_{0}^{+} \simeq-0.085$ であると考えて十分であろう.

次に, Fig. 11 は, 4 通りの $R e$ に関して, 2.(2) の 方法で得られた damping 係数 $A^{+}$を $-<\partial \tau^{+} / \partial y^{+}>$ に対して図示したものであり（ケース $\mathrm{H}-1$ の各実験に 対する $A^{+}$の值は Fig. 8 に示されている), Huffman らによって整理された各種の 2 次元乱流での実験值も併

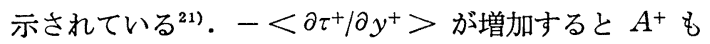
増加するが, $-<\partial \tau^{+} / \partial y^{+}>_{c} \simeq 0.009$ で $A^{+}$は $R e$ の 值にかかわらず急增し, この特性は他の流れでも検証さ れている.すなわち, この遷移限界值で粘性の効果（式 （19）を参照）は急増し，確かに再層流化現象が現われ るといえる. また, 図中の黒丸印は $v_{0}{ }^{+}=0$ での值であ り, 当然 $R e$ が小さいほど再層流化しやすいことがわか る.

最後に, Fig. 12 は $v_{0}^{+}$に対する $A^{+}$の関係を示し， 境界層で得られた実験曲線も併示している ${ }^{7), 8), 18)} . A^{+}$ の決定方法の相違にもよるが，これらの実験曲線は概ね 同様な変化特性を示し, 吹出しで $A^{+}$(粘性効果) は減

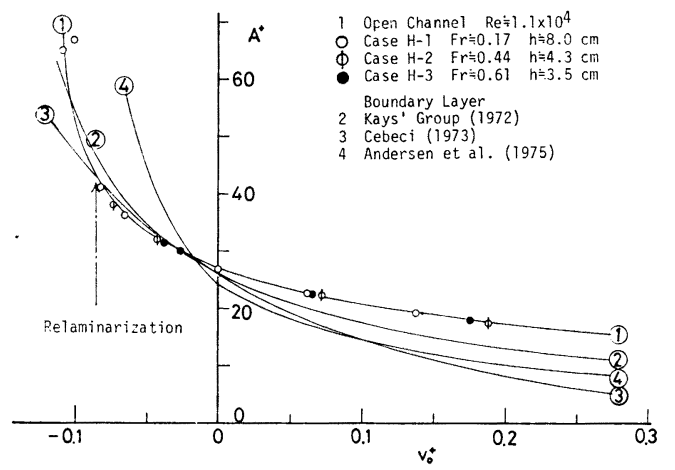

Fig. 12 Variation of $A^{+}$against $v_{0}^{+}$

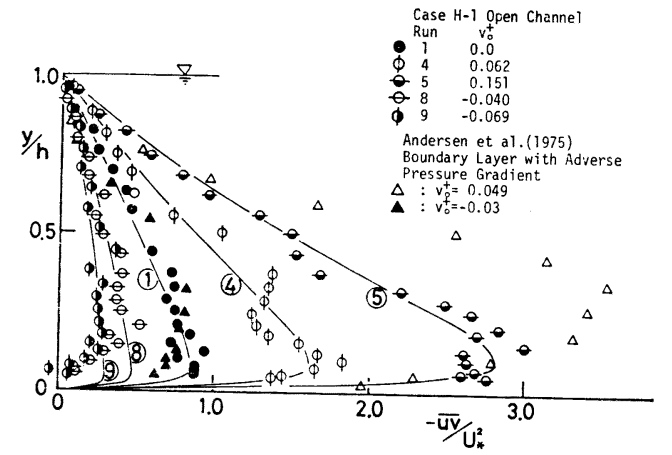

Fig. 13 Reynolds stress distribution

少して剝離現象へ, 逆に吸込みでは増加して再層流化現 象へそれぞれ遷移することがわかる．なお，図中 (1)の 開水路流で得られた実験曲線は

$$
A^{+}\left\{\begin{array}{ll}
=27 /\left(1+4.1 v_{0}^{+}\right) & \left(v_{0}^{+}<0\right) \\
=27 /\left(1+2.7 v_{0}^{+}\right) & \left(v_{0}^{+}>0\right)
\end{array}\right\}
$$

で良好に近似される。

\section{（4） レイノルズ応力分布}

Fig. 13 は，2成分熱膜流速計で実測されたレイノル ズ応力 $-\overline{u v} / U_{*}^{2}$ の分布であり, 式 (16) の理論曲線も 併示している．両者の一致はほぼ良好であり，2．の理 論展開や $\beta-\Omega$ 法の妥当性が確認されるが, 吸込み条件 での壁面近くの実測值は理論曲線よりかなり小さい。こ の原因は現在不明であり, 実験装置等の精巧さや計測精 度などをも含めての再検討がさらに必要であるが，平均 流速分布特性に基ゔいて提案された前節の遷移限界值に 達する以前でも乱れ特性に関しては不十分な抑制された 乱れになることも推測される.

レイノルズ応力は吹出し率が大きいほど増大し，吸込 みでは減少する．他の研究者による実測例があまりな く,ここでは入手し得た Andersen らの実験結果を比 較のため併示したが8)，ほぼ同様な変化特性を示してい る.ただ，彼らの実験值は逆圧力勾配 $(d P / d x>0)$ す なわち減速流で得られたものであるから, 同一の流出入 率 $v_{0}{ }^{+}$でも吹出し的効果が助長され，レイノルズ応力 は全体的に大きくなっている.

このように，レイノルズ応力分布は流出入率によって ほぼ相似に変化する．ところで， $F_{r}$ が小さく，適度の 流出入率では, 粘性応力が無視できる流れの主流部の移 流補正項 $\Phi(\xi)$ は十分小さいから，式 (14) と式 (16) とから

$$
-\overline{u v} \fallingdotseq\left(U_{*}^{2}+v_{0} U_{\max }\right)(1-\xi)
$$

と近似できる.したがって, 摩擦速度として $U_{* m} \equiv$ $\sqrt{U_{*}{ }^{2}+v_{0} U_{\max }}$ を用いれば, 流出入が存在してもみか け上不浸透床上の従来の結果に帰着され, 主流部の速度 欠損則も 


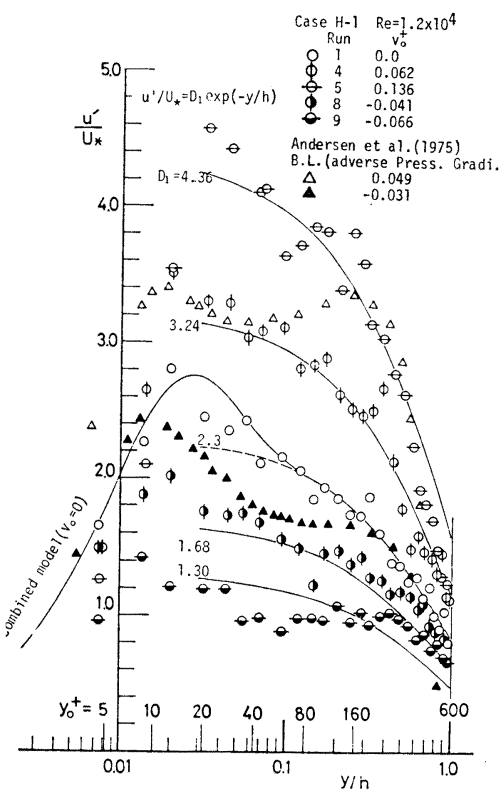

Fig. 14 (a) Turbulence intensity $u^{\prime} / U^{*}$ with transpiration

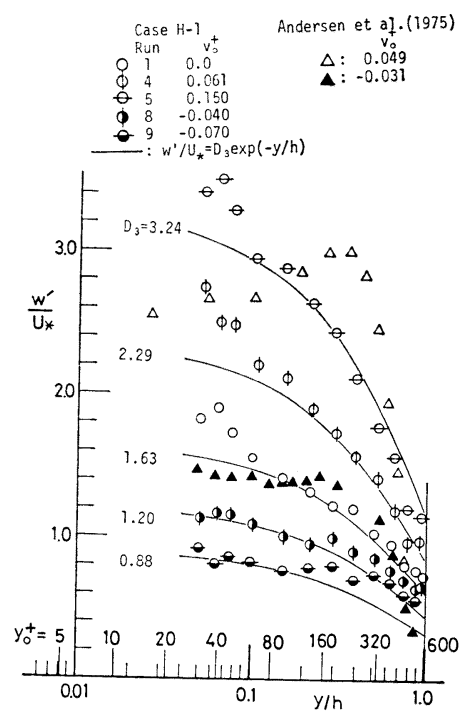

Fig. 14 (c) Turbulence intensity $w^{\prime} / U_{*}$ with transpiration

$\frac{U_{\max }-U}{U_{* m}}=-\frac{1}{\kappa_{0}} \ln \xi$

となる. 式 (31) は, 正しく Mickley らによる速度欠 損則であり ${ }^{22)}$ ，式 (30) はこの表示が近似的に妥当なこ とを示している.

\section{（5）乱れ強度分布}

Fig. 14 (a)，(b) および (c) はケース H-1 で得ら れた $u^{\prime} / U_{*}, v^{\prime} / U_{*}$ および $w^{\prime} / U_{*}$ を示すものである. これらの乱れ強度 3 成分は $v_{0}{ }^{+}$によってほぼ相似に増
減することから, 壁面流出入が存 在しても乱れの普遍的特性 は強 く,ほぼ active 成分に支配され た乱流と考えてよい201.

さて, 不浸透床の場合, $y^{+} z 50$ での乱れの 発生率 $P$ と逸散率 $\epsilon$ とがほぼっり合った平衡領域では 現象論的な考察から次の普遍関数 が提案された20).

$$
\left.\begin{array}{l}
u^{\prime} / U_{*}=D_{1} \cdot \exp (-\lambda \xi) \\
v^{\prime} / U_{*}=D_{2} \cdot \exp (-\lambda \xi) \\
w^{\prime} / U_{*}=D_{3} \cdot \exp (-\lambda \xi)
\end{array}\right\}
$$

ここで, $\lambda=1.0, D_{1}=2.30, D_{2}=$ $1.27, D_{3}=1.63$ である. 一方, 流出入が存在する場合の正確な普 遍関数を提案するまでには至らないが, $v_{0}{ }^{+} \neq 0$ でも乱 れの普遍的特性は強く, 後述するように $P \simeq \epsilon$ となる平 衡領域が確かに存在するから, 式 (32) と同様な指数型 の普遍関数が成立すると考えられ，この場合係数 $D_{i}(i$ $=1,2,3)$ および $\lambda$ は $v_{0}^{+}$の関数となる. 以下では, 簡単のために $\lambda \equiv 1.0$ とおき, $D_{i}\left(v_{0}{ }^{+}\right)$の関数形を検 討した結果, 本実験の範囲内では乱れ成分の方向に関倸 なくほぼ次式が得られた。

$$
D_{i}\left(v_{0}{ }^{+}\right)=\left(1+6.6 v_{0}^{+}\right) D_{i}\left(v_{0}{ }^{+}=0\right) \quad(i=1,2,3)
$$

Fig. 14 には式 (33) を用いての式 (32) を実線で示 したが， $y^{+} \geq 50$ で各成分とも実験值とほぼ良好に一致 している．ただ，吸込み率が大きくなると乱れ強度は極 度に一様化する傾向にあり，式（32）との一致は悪い. これは前節で指摘したようにすでに不十分な乱れとなっ

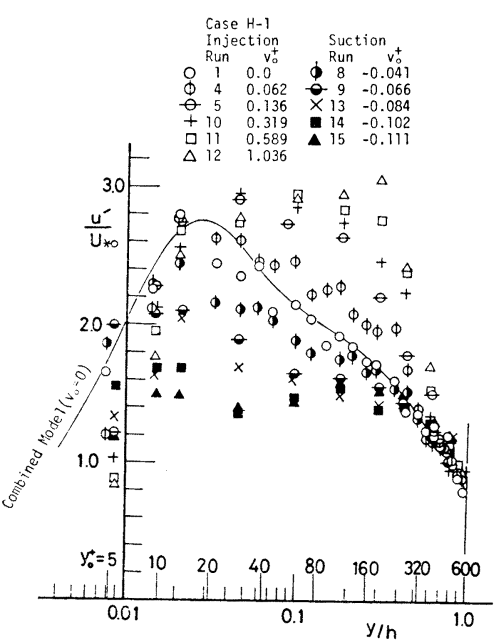

Fig. 15 Absolute variation of turbulence intensity $u^{\prime} / U_{* 0}$ 


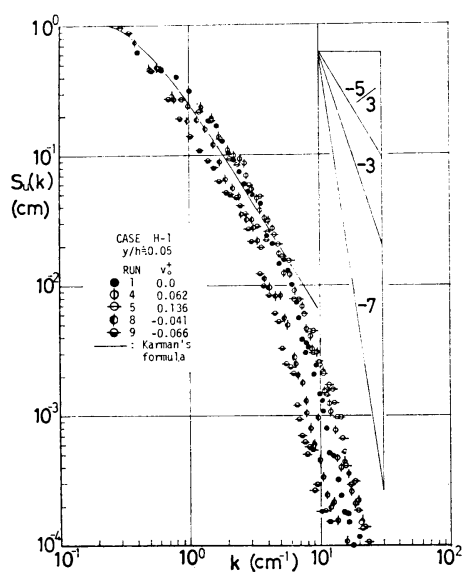

Fig. 16 (a) Spectral distribution at $y / h \fallingdotseq 0.05$

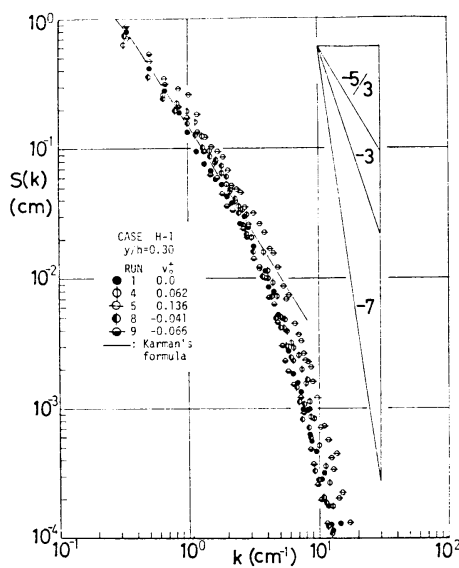

Fig. 16 (b) Spectral distribution at $y / h \fallingdotseq 0.30$

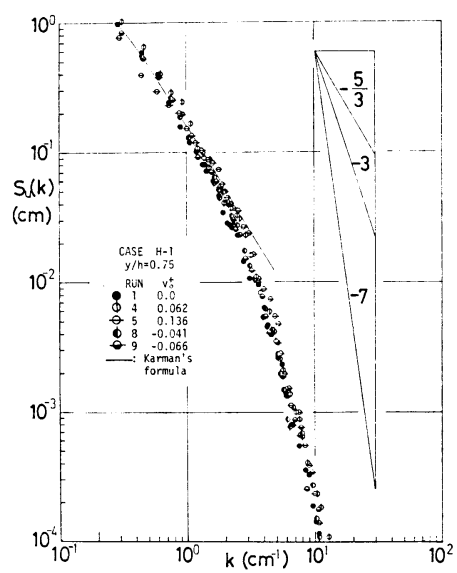

Fig. 16 (c) Spectral distribution at $y / h \fallingdotseq 0.75$
て active 成分とはみなされないためと推測される.な お， $y^{+} \leqq 50$ は乱れの発生に携わる bursting 現象が顕 著に起こる非平衡領域であり, $v_{0}{ }^{+}=0$ の不浸透床です ら不明な点が多い23). Fig. 14 (a) には, このモデル化 (結合モデルという) により得られた理論曲線を併示し たが23), 粘性底層を含めたほぼ全領域で実験值と良好に

\section{一致している.}

以上のような乱れ強度の 普遍特性に関する 検討には

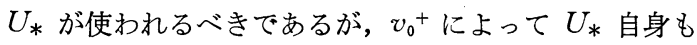
変化するから流出入による乱れ強度の絶対的な変化特性 を検討するには $U_{* 0}$ を使う方が望ましい. Fig. 15 は， ケース H-1 で得られたすべての $u^{\prime} / U_{*}$ の值を示してい る. $v_{0}{ }^{+}=0$ では $y_{0}{ }^{+} \equiv y U_{*_{0}} / \nu \simeq(10 \sim 20)$ の 粘性底層 端で $u^{\prime} / U_{* 0}$ は約 2.8 の最大值をとり ${ }^{20)}$, 吹出し条件 では $v_{0}{ }^{+}$とともに $u^{\prime} / U_{* 0}$ は増大し,この最大値の発生 位置も壁から離れるのに対して, 吸込み条件では逆に減 少し, 最大位置も不明確となって水深方向に一様化する 特性が見られる.しかし, 粘性底層端付近で上述の流出 入による影響は吹出しと吸込みとで逆転する傾向にあ り, 注目される.

このように, 平衡領域までの主流域では乱れは吹出し で促進され, 逆に吸込みで抑制される結果となり, 壁面 流出入によって乱れを制御できる可能性があるが，この 効果は自由水面領域 $(y / h \geq 0.6)$ にはほとんど波及しな いようである。

\section{（6）スペクトル分布および特性渦スケール}

$\mathrm{F} \cdot \mathrm{F} \cdot \mathrm{T}$ 法で速度変動 $u$ の スペクトル解析を行い, Fig. 16 (a)，(b) および (c) にそれぞれ壁面領域, 平 衡領域および自由水面領域の代表測点で得られた結果を $u^{\prime 2}$ で規準化して示した. 波数スペクトル分布 $S_{u}(k)$ に 及ぼす流出入の影響は壁面領域㧍よび平衡領域には明白
に現われているが，自由水面領域にはほとんど現われな い. すなわち, 壁面近傍の $S_{u}(k)$ は, $-5 / 3$ 乗則が成 立する慣性小領域以上の高波数領域で吹出しを与えると 増加し, 一方吸込みを与えると減少する. したがって, $L_{x}=(\pi / 2) S_{u}(0)$ で評価される平均渦径 $L_{x}$ は吹出しを 与えると逆に減少すると予測され， $S_{u}(k)$ をこの $L_{x}$ で 無次元化すれば普遍表示できそうであり，この一例が

Fig. 17 に示される. 確かに, スペクトル分布 $S_{u}(k)$ を $L_{x}$ で無次元化すれば $v_{0}^{+}$によらずにほとんど普遍 関数表示され, きわめて注目される. 図中の実線は, せ ん断乱流に関して慣性小領域までは Karman の式, 粘 性小領域には Heisenberg の式をそれぞれ適用し, 逸散 スペクトル,すなわち

$$
\int_{0}^{\infty} k^{2} S_{u}(k) d k \equiv \lambda_{x}{ }^{-2}
$$

が等方性乱流からの $\epsilon / 15 \nu u^{\prime 2}$ に一致するように両者を

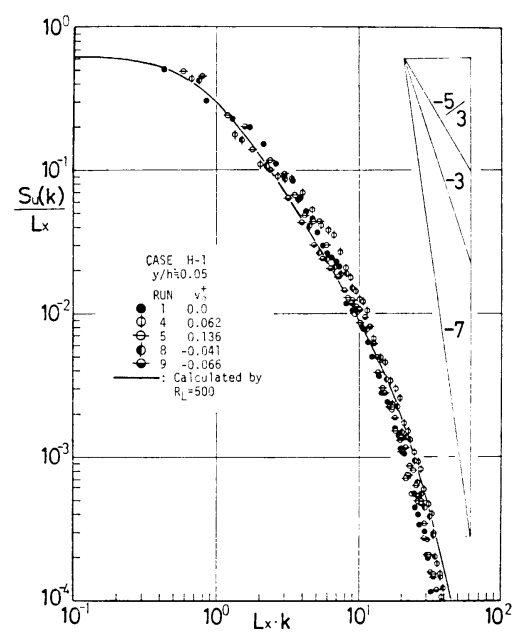

Fig. 17 An example of spectra normalized by $L_{x}$ at $y / h \fallingdotseq 0.05$ 
Fig. 18 Macro-and micro-scales with transpiration
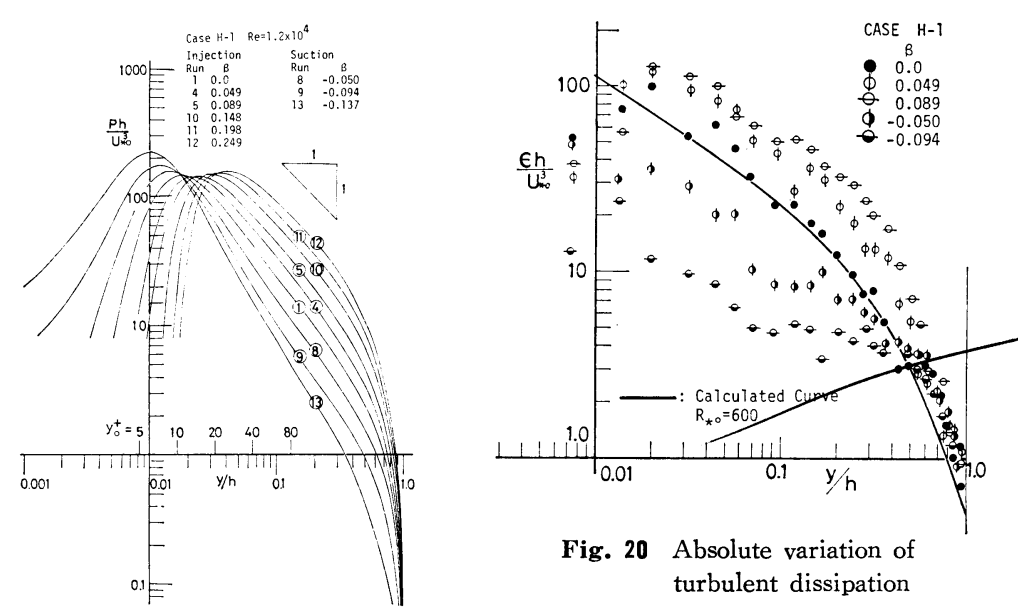

Fig. 20 Absolute variation of turbulent dissipation

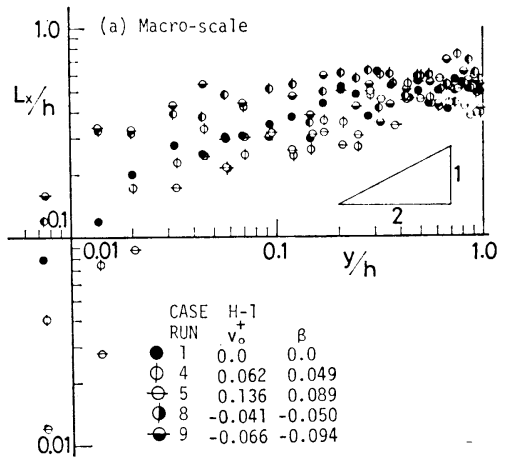

なかったが, $v_{0}=0$ での詳細な 実験結果から主流域での $T_{r} /$ $U_{* 0}{ }^{3}$ はたかだか $(1+4 \beta)$ 程 度であり, $R / U_{* 0}{ }^{3}$ も同程度と 考えられることから ${ }^{17)}$, 式 (35) の右辺第 2 項の拡散率はせいぜ い2 程度以下であり, 自由水面 領域で重要となる。

さて, Fig. 19 は式 (16) と (18) から計算された乱れの発 生率 $P \equiv-\overline{u v} \partial U / \partial y$ である.

また，Fig. 16 でみられたよう に波数スペクトルにはー5/3 乗 則が成立する慣性小領域が存在 するから Kolmogoroff の普遍 定数を使って乱れの逸散率 $\epsilon$ が 評価され，この実験值が Fig. 20 に示される. 図中の実線は Fig. 17 の理論曲線から計算さ れたものである ${ }^{17)}$.

図明らかなように, $y / h$ $\leqq 0.6$ なる主流部では発生率お よび逸散率は拡散率より十分大 きく, 式 (35) で示されるよう に $P \simeq \epsilon$ となる.すなわち, 壁 面流出入が存在しても乱れの発 生はほぼその逸散とつり合い, 乱流構造はほぼ平衡状態にある

Fig. 19 Absolute variation of turbulent production

内挿した理論曲線である ${ }^{17)}$. 実験值と理論曲線との一致 は全波数で比較的良好であり, 壁面流出入が存在しても 乱れの self-consistency は強く, active 成分に支配された 乱流であるという先述の議論の妥当性を裏付けている.

次に, Fig. 18 は, マクロスケール $L_{x}$ とミクロス ケール $\lambda_{x}$ とを図示したものである. $v_{0}=0$ のとき $L_{x} / h$ は $y / h$ の $1 / 2$ 乗則, $\lambda_{x} / h$ は $1 / 3$ 乗則にそれぞれほぼ 従うが ${ }^{17)}$, 両渦スケールともに $y / h \leqq 0.6$ の領域で吹出 しのとき減少し, 一方吸込みでは増加して水深方向にほ ぼ一様化することがわかる ${ }^{17}$.

\section{（7）乱れエネルギーの収支関係}

レイノルズ数が十分大きいときの乱れエネルギー式は 次のように近似される ${ }^{17)}$.

$$
\frac{P h}{U_{* 0}{ }^{3}}=\frac{\epsilon h}{U_{* 0}{ }^{3}}+\frac{\partial}{\partial \xi}\left\{\frac{T_{r}+R}{U_{* 0}{ }^{3}}\right\}
$$

ここで, $T_{r} \equiv \overline{\left(v+v_{0}\right) q^{2} / 2}, R \equiv \overline{p v} / \rho, q^{2} \equiv u^{2}+v^{2}+$ $w^{2}$ である. 本研究では $T_{r}$ および $R$ の実測は行われ
といえる. 発生率, 逸散率ともに吹出しでほぼ相似に増 大し, 吸込みで減少するが, 粘性底層内ではこの増減は 逆転する特性が見られる. すなわち, 粘性底層内では吸 込みほど乱れの発生率は大きく, 先述の乱れ強度の変化 特性をよく説明している.

\section{5. 結 論}

本研究は河床境界面を通しての水流の出入りが開水路 流の乱流構造にいかなる影響を及ぼすかを理論的・実験 的に考察したものである. 従来開水路乱流に関するこの 種の研究がほとんど行われていない現状にかんがみて, まず平均流特性を詳細に検討し, 次に乱れ特性の基礎的 な解明に努めた. 本研究で得られた主な結果を列挙すれ ば次のと拈である.

（1）流出入速度が摩擦速度の 1 割以内でもこの乱流 構造には顕著な影響が現われる.すなわち, 壁面せん断 応力は吹出しで減少し, 極端な場合剝離現象に, 一方吸 込みでは増加して, 極端な場合, 再層流化現象にそれぞ 
れ遷移する.

（2）流れが十分に発達した乱流である限り，流出入 が存在しても混合距離モデルが良好に適用され，ほぼ全 領域にまで成り立つ普遍的な流速分布則（壁法則）が得 られる。

（3）過大な吸込み率ではもはや乱流状態は維持され ず，再層流化する．この遷移基準として壁面領域端まで のせん断応力の平均勾配をパラメーターにとれば, 加速 流を伴う場合や限界レイノルズ数近傍での再層流化など 各種の流れで生じる再層流化現象を統一的に説明するこ とができる.

（4）再層流化比至らない適度の流出入率では, 摩擦 速度で無次元化された乱れ強度はほぼ普遍特性分布を示 す.すなわち, 流出入が存在してもなお乱れの active 成分は強く, 乱流構造は相似的に変化する.

（5）乱れ強度や逸散率などの乱れ特性值の絶対変化 は吹出しで増加し, 吸込みで減少して一様化に向かう. 流出入の影響はほぼ平衡領域までに現われ, 自由水面領 域では消減する.この傾向はスペクトル分布にも明膫に 認められ，一般的な特性と考えられる.

以上の結果を総括して現象論的にいえば次の結論が得 られよう.すなわち, 自由水面近傍に及ぼす流出入の影 響は小さいことから，吹出しを与えると壁面近傍の小さ な渦が浮上されて水深方向に非一様化に向かい，も万も ろの乱流特性の分布は急な勾配をもつようになって乱れ は促進される.一方，吸込みを与えると自由水面側の大 きな渦が吸い寄せられて一様化に向かい，次第にせん断 乱流の特性を失って乱れは抑制される.

このように，壁面流出入を適宜与えると壁面近傍の乱 流構造は顕著に変化する. したがって, 壁面流出入の影 響に関する知見はせん断乱流の乱れ発生機構, すなわち bursting 現象の解明 という基礎的研究に有益であるば かりか, 乱流の制御というより価値のある応用的研究に 寄与する所は大きいと考えられ, 今後これらの研究課題 を系統的に進めていきたいと考えている.

最後に, 本研究を遂行するのに予備実験から一貫して ご協力願った当時の京都大学院生 為沢長雄 (水資源公 団勤務), 藤原吉美 (関西電力勤務), 大仁孝太郎 (大阪 府勤務）および松本直也（建設省勤務）の各氏に対して 束心から謝意を表したい。

\section{参 考 文 献}

1) Dorrance, W.H. and Dore, F.J. : The effect of mass transfer on the compressible turbulent boundary layer skin friction and heat transfer, J. Aero. Sci., Vol. 21, pp. 404-410, 1954.

2) Black, T.J. and Sarnecki, A.J. : The turbulent boundary layer with suction or injection, Aero. Res. Coun., R \& M., No. 3387, 1958.
3) Stevenson, T.N. : Turbulent boundary layers with transpiration, AIAA J., Vol. 2, pp. 1500-1502, 1964.

4) Tennekes, H. : Similarity laws for turbulent boundary layers with suction or injection, J. Fluid Mech., Vol. 21, pp. 689-703, 1965.

5) Simpson, R.L., Moffat, R.J. and Kays, W.M. : The turbulent boundary layer on a porous plate : experimental skin friction with variable injection and suction, Int. J. Heat Mass Transfer, Vol. 12, pp. 771789, 1969.

6) Julien, H.L., Kays, W.M. and Moffat, R.J. : Experimental Hydrodynamics of the accelerated turbulent boundary layer with and without mass injection, AS ME, J. Heat Transfer, pp. 373-379, 1971.

7) Kays, W.M. : Heat transfer to the transpired turbulent boundary layer, Int. J. Heat Mass Transfer, Vol. 15, pp. 1023-1044, 1972.

8) Andersen, P.S., Kays, W.M. and Moffat, R.J. : Experimental results for transpired turbulent boundary in an adverse pressure gradient, J. Fluid Mech., Vol. 69, pp. 353-375, 1975.

9) Escande, L. (中山謙二訳)：境界層の吸込みによる流況 の変更, 土木学会誌, 第 48 巻, pp.4-8, 1963.

10）中川・袮津・為沢・大仁：壁面を通しての流出入を伴う 開水路乱流の特性, 土木学会関西支部年講, II-30, 1976 .

11）為沢長雄・中川博次・袮津家久：開水路乱流場に及ぼす 浸透流の影響について, 第 31 回土木学会年講, II-223, 1976.

12）松本直也・祢津家久・中川博次：吸込みや吹出しを伴う 開水路粗面乱流の特性, 第 32 回土木学会年講, II-152, 1977.

13) Torii, K., Nishiwaki, N. and Hirata, M. : Heat transfer and skin friction in turbulent boundary layer with mass injection, Proc. 3rd Int. Heat Transfer Conf., pp. 34-48, 1965.

14）中川博次・祢津家久：水路休からの吹出しや吸込みを伴 開水路乱流の構造, 第 10 回乱流 シンポジウム, pp. 162-169, 1978.

15) Bradshaw, P. : Mixing-length velocity profile in boundary layers with transpiration, AIAA J., Vol. 5, pp. 1674-1675, 1967.

16) Kinney, R.B. : Skin-friction drag of a constant-property turbulent boundary layer with uniform injection, AIAA J., Vol. 5, pp. 624-630, 1967.

17）袮津家久：開水路流の 乱流構造に関する 基礎的研究, 京 都大学学位論文, 1977 .

18) Cebeci, T. : Variation of the van Driest damping parameter with mass transfer, AIAA J., Vol. 11,pp. 237-238, 1973.

19) Patel, V.C. and Head, M.R. : Reversion of turbulent to laminar flow, J. Fluid Mech., Vol. 34, pp. 371392, 1968.

20）袮津家久：開水路乱流の乱れ強度に関する研究, 土木学 会論文報告集，第 261 号，pp. 67-76, 1977.

21) Huffman, G.D. and Bradshaw, P. : A note on von Karman's constant in low Reynolds number turbulent flows, J. Fluid Mech., Vol. 53, pp. 45-60, 1972.

22) Mickley, H.S., Smith, K.A. and Fraser, M.D. : Velocity defect laws for transpired turbulent boundary layers, AIAA J., Vol. 3, pp. 787-788, 1965.

23）中川博次 - 袮津家久 : せん断乱流の bursting 現象とその 物理モデル, 第 22 回水理講演会論文集, pp. 29-36, 1978.

(1978.8.1 · 受付) 